\title{
Sección
}

\section{La Santa Muerte y LA CUlTURA \\ DE LOS DERECHOS HUMANOS}

\author{
Pilar Castells Ballarin
}

Resumen: Este artículo tiene su origen en la siguiente pregunta: ¿qué valores se construyen en el culto a La Santa Muerte y cómo afectan el contexto socio-simbólico de los derechos humanos? Reflexiono el culto a La Santa Muerte como un fenómeno social con dos pautas: 1. Una original expresión estratégica para enfrentar la precariedad y muerte social (como efectos indeseados del neoliberalismo); 2. Una expresión que confirma la cultura del miedo como instrumento de control social.

Palabras clave: Santa Muerte, Estado, ciudadanía, derechos humanos, violencia, jerarquía, culto.

Enviado a dictamen: 14 de enero de 2008. Aprobación: 17 de marzo de 2008.

Pilar Castells Ballarin, licenciada en Derecho y doctora en Sociología por la Universidad de Barcelona, España, investigadora, miembro de Copolis (grupo de investigación de la Universidad de Barcelona). Temas de especialización: identidad, cultura de los derechos humanos, muerte, correo electrónico: pcballarin@yahoo.es.
Abstract: This article is a result of the question: which values are builded concerning to the Holy Death cult and how do ts these values affect the Humans Rights sociombolic sociosymbolic context in which the cult is popular? I think about the social phenomenon ruled by twomodels: (1) an strategic and original expression to face precariety and social death (as undesirable effects of neoliberalism); (2) an expression that confirmes the fear's culture as a mecanism of social control.

Key words: Santa Muerte, State, citizenship, human rights, violence, hierarchy, cult.

\section{Introducción}

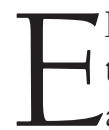
l auge del culto a La Santa Muerte es manifiesto. Al menos desde el año 2000 han aparecido artículos en medios de comunicación masivos como La Jornada y La Crónica, Massiosare, National Geographic en español y en la página web de la BBC. Hay libros publicados con diferentes enfoques y sobre diversos aspectos del culto. La página de noticias del Conaculta se ha ocupado, en varias ocasiones, de las interpretaciones sobre el tema ${ }^{1}$ desarrollados sobre todo por Elsa Malvido y Katia Perdigón. La Santa Muerte aparece en el número 76 de noviembre-diciembre de la revista Arqueología, también del Conaculta. El especialista en temas religiosos Bernardo Barranco reflexiona sobre el 
tema en algunos artículos. Hay novelas y una película reciente que incluyen a la figura. En 2006 se publicó en español la primera edición del libro de Claudio Lomnitz, Idea de la muerteen México, que incluye a su vez un capítulo con La Santa Muerte bajo el título de "La indomable" (Lomnitz, 2006: 457-469).

El énfasis de estos materiales se dirige al origen y extensión territorial y social del fenómeno; la iconografía de la imagen, geográficamente, se han ceñido, sobre todo a los altares y al llamado santuario ${ }^{2}$ de La Santa Muerte en el Distrito Federal. Los medios de comunicación, en general, lo han señalado como un culto violento y con insistencia en su marginalidad. Se presenta vinculado con una situación económica difícil y con el ánimo desesperado de la población. Se discute si es una actualización sincrética del culto a la muerte en las culturas prehispánicas o si su antecedente es cristiano. Se alude a la investigación realizada por Navarrete sobre San Pascualito Rey (La Santa Muerte) ${ }^{3}$ escondido en el nombre de San Pascual Bailón, en Tuxtla Gutiérrez, como ejemplo de la ruta Europa-América de la calavera en el culto.

\section{¿Es violento el culto a La Santa Muerte?}

La primera impresión que se recibe de La Santa Muerte es que se trata de un culto efectivamente violento. ¿Pero es realmente así? ¿Qué valores y principios éticos se manejan entre quienes siguen este culto teniendo en cuenta que le son afines desde las poblaciones callejeras a las clases medias y altas, es decir, amplios y muy diferentes segmentos sociales? ¿Cómo se cimenta este culto en un contexto marcado por otros imaginarios protectores como el de los derechos humanos? Hasta ahora, de las entrevistas realizadas y del material analizado, entiendo que al acercarse a cualquiera de las variaciones ${ }^{4} \mathrm{de} \mathrm{La}$ Santa Muerte, cada ser humano contribuye a generar un laberinto con muchas posibilidades. Hay en ese laberinto un gran vestíbulo inicial, muy abierto y transitado con el denominador común del inicio de la oración a La
Santa Muerte: Jesucristo vencedor que en la cruzfuistevencido; la antesala tiene un ramal de problemas a la vista: el que enfrenta a creyentes católicos con el fundamento del cristianismo, tal como dice un sacerdote católico: "es como ya declararnos a nosotros sus enemigos, porque para nosotros, Cristo venció a la muerte en la cruz" la Iglesia Católica sólo hace una condena verbal mientras que quienes reciben la condena no quieren problemas ni ven conflicto alguno entre su catolicismo o su fe y su adscripción a la Santa condenada. Otro trayecto es el de la protección de la violencia exacerbada, que tiene varios itinerarios:

1. Grupos violentos organizados al estilo militar, cuyo ideario está vinculado con Satanás y que tienen a La Santa Muerte como intermediaria, por ejemplo, La Mara Salvatrucha, $13 .{ }^{6}$

2. Policías y delincuentes que individualmente, en la calle o en la cárcel se sobreprotegen con la imagen contra el riesgo de tener una muerte violenta. Estos últimos son los espacios del laberinto que han dado pie a teñir la figura con el estigma de la violencia.

Un itinerario muy concurrido es el que recorren las personas comunes, quienes no contribuyen a la violencia exacerbada como amas de casa, funcionarios, docentes, personas con negocio propio, etcétera; y quienes se han acogido a La Santa Muerte como una opción más a las lealtades que ya tienen, o bien ésta ha sustituido por entero a las anteriores. Este sector es amplio, heterogéneo, comparte espacio con otras religiosidades e incluye a las personas que se denominan curanderos y que trabajan con La Santa Muerte, como única fuente de protección en su altar o en compañía de otras imágenes. Esta bifurcación del laberinto es la mayor generadora de peticiones diversas de protección y, en consecuencia, de valores y de principios éticos, puesto que lo que se pide interviene en la percepción y construcción del mundo cotidiano. En este espacio, precisamente, una de las figuras clave es la de esos curanderos que actúan como re-mediadores entre 
sus clientes y La Santa Muerte. Cabe destacar que en esta sección del laberinto la violencia exacerbada no es el tema común, sino una opción entre otras más amigables.

\section{Construcción de la identidad de La Santa Muerte}

Hay un sello de originalidad en el culto a La Santa Muerte que quizá estriba en la convergencia de varios aspectos, algunos obvios, otros más escondidos. Señalo algunos:

1. Es un culto que, aunque existe de forma aislada y secreta, explota y se hace público entre diferentes segmentos sociales a fines del siglo XX, sigue en el transcurso del siglo XXI y su proceso ulterior está por verse; está asociado a México sin ser exclusivo de los mexicanos, puesto que tiene seguidores originarios de otros países; coexiste confundida con otras imágenes que le prestan el nombre, por ejemplo, San Bernardo en Hidalgo y San Pascualito Rey en Tuxtla Gutiérrez, Chiapas, pero parece reafirmarse la propia figura de La Santa Muerte?

2. La Santa Muerte sustenta, además, su fuerza de ser en la apropiación de la muerte, a través de su materialización/cosificación en la representación de una calavera completa; y realiza su fuerza en el territorio de la vida, el cuerpo vivo. Desde esa situación incontrovertible se iconiza e irradia su validez y legitima la esperanza que se pone en ella.

3. La muerte produce el efecto social de igualar las individualidades. Las diferencias de poder o posición económica no tienen valor al morir, pues se arrasa con todo al acabar la vida que sustenta esos contrastes. La frase cotidiana que lo ilustra es: "pobre, no le ha valido de nada el dinero, se ha muerto como todos".

4. La muerte representa, también, la no indiferencia al dolor, la miseria o la opresión y se hacen frases como: "suerte que murió, pobre, para tanto sufrir", "Por fin ha dejado de sufrir", "para vivir de rodillas es preferible morir". Estos contenidos se despla- zan, a su vez, hacia La Santa Muerte y la moldean con significado claros de entidad superior que hace justicia al igualar a todos los mortales en un acto definitivo e innegociable.

Pero, sin confundirnos, La Santa Muerte no es la muerte. La muerte es un concepto para significar el fin último de un tipo de organización celular que impide que una persona siga desarrollando la posibilidad mínima de existir. Dicho proceso conlleva un proceso de desorganización tal que impide la existencia del cuerpo sustentador del concepto persona. Se trata de un fenómeno muy desconocido; es, sobre todo, un proceso medicalizado y redefinido en el siglo XX (Castells, 2002), del que universalmente se advierte el resultado: desaparición progresiva de las materias blandas y cierta perdurabilidad de la osamenta, la calavera o fragmentos de la misma en caso de incineración. La primera cosificación de la muerte es la calavera. La muerte-calavera se cosifica de nuevo y se diversifica en imágenes, ${ }^{8}$ como la que luce La Santa Muerte que, no hay que olvidar, va envuelta en ropajes que le otorgan un poder diferente. Los colores rojo, negro, blanco, amarillo con que se viste, refieren las necesidades y deseos y probablemente quieren expresar que el paso exitoso por la vida precisa de la realización de los mismos. Esa es su identidad, la misma que la distancia de cualquier otra variedad de calavera. Y esa identidad es la que dibuja un eje organizador del mundo en el que la muerte santificada se hace metáfora gobernadora del cumplimiento de las peticiones de la persona que la invoca. La Santa no desdeña deseos complejos que involucren aspectos contradictorios incorrectos o ilegales, tales como la muerte de terceros o la sumisión de otra persona, y admite deseos tradicionalmente asociados con otras imágenes del ritual católico popular: trabajo, San Pancracio; imposibles, Santa Rita y San Expedito; protección a la familia, la Sagrada Familia; el éxito en el cruce de fronteras para personas indocumentadas ${ }^{9}$ y muchas otras posibilidades. ${ }^{10}$

El trato con La Santa Muerte abarca ofrendas muy diversas, tantas como los deseos pedidos, puesto que a 
ella se llega con fundamentos y valores preexistentes: esoteristas, católicos, maras, ${ }^{11}$ gente dentro y fuera de la ley que, desde esa situación, recombinan en el nuevo culto su propio fundamento y ética de vida. Hay quien dice que esta devoción le ha hecho ser mejor persona o mejorar su vida; ${ }^{12}$ y hay quien mata indiscriminadamente para ofrendarle vidas. ${ }^{13}$ Aunque está admitido el compartir este culto con el de otros santos, hay una tendencia marcada a su exclusividad "porque la Santa es muy celosa". ${ }^{14}$ Por encima de La Santa Muerte sólo se coloca a Dios (buena parte de cultistas) o a Satanás (La Mara Salvatrucha). Ocupa, pues, un lugar intermedio de intercesión entre los seres humanos y una entidad superior. El culto es individual, colectivo y público, con altares caseros abiertos, altares en la calle e iglesias. Hay al menos una en México, D.F. conocida por dedicarse a su culto; la iglesia de San Pascualito Rey, también identificado como Santa Muerte, en Tuxtla Gutiérrez, Chiapas. Destaca el rezo colectivo de rosarios en fechas determinadas. Además, hay que añadir todo el intercambio de conocimientos, rutinas, consumo, tendencias, a través de revistas; páginas web, comercios y un sinfín de posibilidades en las que la gente interesada puede actualizarse sobre conductas a seguir en su culto. ${ }^{15} \mathrm{Sin}$ embargo, sigue siendo muy informal y poco reglamentado. Sus seguidores actúan de corazón, según lo que perciben como apropiado para el caso, e incorporan lo que van aprendiendo en el mismo sentido.

El culto a La Santa Muerte se alimenta, sobre todo, de la propia experiencia de la gente y las diferentes opiniones sobre su posible origen indican remisiones a los gustos y opiniones de cada uno, sin que importe demasiado la falta de unanimidad en cuanto a su fuente originaria (prehispánica, colonial, sincrética o actual). Es una construcción cultural de gran vitalidad y dotada de una fueza.

Yo la defiendo [a La Santa Muerte] - me contesta - hay gente a quien no le cae bien. Supe de ella en Honduras. Aquí en el mercado la vi por primera vez. ¿Esa es La Santa Muerte?, pregunté. Sentí una alegría en mi pecho. Para mí, está primero Dios y luego La Santa Muerte. Yo le comento, que los maras le ofrecen vidas (Ella no, no está ligado con la maldad). La Santa Muerte me protege, me ha permitido viajar, sin que me pase nada. ${ }^{16}$

Esa diversidad no impide identificar elementos comunes del culto que se anclan en su imagen: esqueleto erecto o sentado que muestra rostro y manos, mientras que el cuerpo va vestido. Como complementos puede lucir una guadaña, el globo del mundo, una balanza y los que convengan según el imaginario popular. Guadaña, globo terráqueo y balanza son símbolos de límites culturalmente heredados del género humano, construidos, pensados como evidentes: territorios y mecanismos de medición. ${ }^{17}$ ¿Hay en este culto una obsesión de los propios límites? Tiene la caducidad marcada por la certeza de la muerte, pero también es observable en la imagen con el cuerpo completo hecho de huesos un importante principio organizador que huye de la descomposición, del desorden, en definitiva de la anomia. Cultos como el de La Santa Muerte son apuestas hacia la solución individual de problemas como la enfermedad, búsqueda de trabajo, pago de una matrícula para estudiar, vivienda, problemas de convivencia. Y aquí surgen sospechas. Por ejemplo, ipor qué prospera este referente en una sociedad que ha crecido bajo la protección de los derechos humanos?

\section{Elegir entre los derechos humanos y La Santa Muerte}

Los derechos humanos hablan de cosas necesarias y cotidianas: vivienda, trabajo y salario dignos, libertad de creencias y prácticas religiosas, derecho a la vida, a la seguridad. Aunque conciernen a los seres humanos, individualmente considerados, requieren de la cooperación y de los actos individuales concurrentes 
al bienestar común para poder ser disfrutados, pues si una persona o pocas acapararan un determinado bien, servicio o valor, no permitirían el ejercicio del mismo al resto. Son los derechos humanos los que han organizado las bases de la convivencia, pues una vez proclamado el derecho a existir y asegurado nuestro lugar en el mundo, no importa quiénes seamos ni de dónde vengamos. ¿Por qué no se refuerza la exigencia de su cumplimiento al Estado? ¿Por qué no se apuesta por ellos? La respuesta está, tal vez, en otras preguntas: ¿Cuál, entre ambos imaginarios, el de La Santa Muerte y el de los derechos humanos, regula mejor la incertidumbre ante los retos diarios? ¿Cuál encauza mejor los deseos de bienestar?

El siglo XX es el momento cuando el imaginario de los derechos humanos confirma y actualiza su universalidad, quedando su gestión a cargo de cada EstadoNación. En dicha gestión destacan dos tendencias marcadas por las circunstancias políticas que se cruzan en el siglo XX. Una remarca los derechos civiles y políticos, centrados en la individualidad por encima de lo colectivo; y la otra se enfoca en los derechos colectivos sin espacio para la individualidad. En resumen, el resultado de esas tendencias es que en una se manejan indicadores de libertad de prensa, partidos políticos que acceden al poder a través de elecciones libres y se consideran irrelevantes las diferencias abismales riqueza/pobreza; mientras que en la otra, se maneja el bien colectivo como modelo y se consideran irrelevantes los derechos individuales y la libre expresión. A fines del siglo XX, con la Conferencia Mundial de Viena (1993), se desdibuja el énfasis anterior en uno u otro enfoque y se restablece el espíritu de complementariedad individual y colectiva que da la Declaración Universal de Derechos Humanos de 1948, surgida tras una guerra mundial entre potencias que afectó la definición de los valores humanos. Esta declaración es, o aspira ser, un marco de inspiración de comportamientos, fundamentado en la libertad e igualdad incondicionados de los individuos, puesto que con los derechos humanos se busca el "advenimiento de un mundo en el que los seres humanos, liberados del temor y de la miseria, disfruten de la libertad de palabra y de la libertad de creencias"18 y se proclama un ideal común en el que 'pueblos y naciones' deben esforzarse con el fin de que tanto los individuos como las instituciones, inspirándose constantemente en ella, promuevan mediante la enseñanza y la educación, el respeto a estos derechos y libertades, y aseguren, por medidas progresivas de carácter nacional e internacional, su reconocimiento y aplicación universales y efectivos".

Ahora bien, iqué hay de ese esfuerzo de promoción eficaz y aplicación de los derechos humanos en México? La Declaración de México ${ }^{19}$ de 2001 resume los problemas del conjunto de países de la zona, incluido México:

La región comienza el siglo XXI en un contexto político, económico y social caracterizado por la desigualdad, no sólo de individuos sino de pueblos y comunidades que viven en la marginalidad social, en la pobreza y excluidos de los beneficios del desarrollo económico. A pesar de las numerosas promesas de las políticas económicas, los programas de ajuste estructural y los proyectos de reforma del Estado puestos en marcha por gobiernos e instituciones multilaterales en América Latina y el Caribe, la realidad refleja una enorme concentración de la riqueza que hace de esta región la más desigual del planeta. Además, fenómenos como la corrupción, la impunidad, el desigual acceso a la justicia, el deterioro de las condiciones de vida y del medio ambiente, el desempleo, el déficit en vivienda, la salud y la alimentación, han conducido al recrudecimiento de la criminalidad y la inseguridad, lo cual limita la participación y los procesos de organización ciudadana. Los avances en derechos humanos son todavía precarios (UNESCO, 2001: 1-2).

Es decir que los derechos humanos están en el limbo de las promesas incumplidas y la situación que describe el entrecomillado es el escenario de una disociación entre el imaginario esperado y la realidad vivida. No ha habido 
un esfuerzo institucional suficiente y sostenido, desde los aparatos del Estado, para desplegar el necesario marco propicio para un mejor desarrollo humano y, por tanto, no ha progresado el modelo cultural de los derechos humanos, cuyo germen está en el pronunciamiento articulado de la Declaración de 1948. Y resulta que, por ejemplo, los derechos proclamados a la igualdad (artículo uno); nivel de vida adecuado (artículo 25), son derechos precarizados que han crecido de forma concentrada; personas que poseen múltiples viviendas lujosas frente a otras que no poseen ni una para cobijarse.

En México, además, ese proceso coincide con un histórico cambio de partido en el gobierno que no se había dado en décadas. El nuevo partido gobernante señalaba el logro de los derechos humanos como una meta a conseguir y también la lucha contra la pobreza como uno de los objetivos del sexenio. Sin embargo, los Informes sobre Desarrollo Humano (Resumen ejecutivo, PNUD-México: 2002, 2006 y 2007) advierten que esos problemas siguen. A su vez, el representante en México de la oficina de la Alta Comisionada de DDHH de la ONU señala que las prioridades deberían ser la lucha contra la pobreza, la discriminación y la impunidad, ya que son los inconvenientes más agudos para el ejercicio de los DDHH en el país. ${ }^{20}$ El Informe sobre Desarrollo Humano de 2004 señala, entre los obstáculos para los DDHH, "la débil protección a la integridad física y patrimonial de los individuos". Paralelamente, un mexicano es identificado por la revista Forbes como uno de los hombres más ricos del mundo.

Es obvio que ha habido progreso: un hombre se ha hecho uno de los más ricos del mundo, pero es evidente también que ese progreso no se ha vinculado con el modelo de los derechos humanos sino con el programa neoliberal que ha logrado resultados semejantes en otros tantos países; es decir, una mayor concentración de riqueza en pocas manos y, para la mayoría, una mayor incertidumbre en la manera de resolver el presente y el futuro, puesto que el gran sistema organizador de la vida, el Estado a través de sus aparatos, pierde sentido en el modelo económico neoliberal. De alguna manera, el Estado está en su punto de inflexión generalizado, puesto que ahora se sienten sus efectos más ampliamente y eso lo convierte en un modelo sufrido en lugar de un esperanzador modelo teórico. La supremacía del dinero y de los indicadores financieros en detrimento del trabajo, por ejemplo, provocan un torbellino en el que circula la incertidumbre (de comida asegurada, de trabajo, de preguntarse "para qué sirven mis estudios", de "pareja hoy y quién sabe mañana", de "para qué trabajar si otros se hacen ricos").

Esa fluctuación se hace más fuerte con la conciencia de los riesgos acumulados y la mayor inseguridad que genera una sociedad con un uso exacerbado de la tecnología y un fácil acceso a técnicas para matar. Al tiempo que se es más consciente que nunca de esos riesgos, se carece de la iniciativa y los medios para mejorar la seguridad. Todo ello ha conformado lo que Ulrich Beck define como "sociedad de riesgo" (2002), una experiencia de vida en la que el nivel de incertidumbre es muy elevado al confluir circunstancias de modificaciones cruciales en el ámbito económico, institucional, familiar y social en un contexto marcado por la oscilación de todos los bienes y valores. Una práctica de vida en que la violencia, las desigualdades y el conocimiento de la impunidad de algunas personas y colectivos son ingredientes cotidianos. Se agudizan las dudas, se piensa en términos de perplejidad y falta de alternativas, todo esto provocado en buena medida por privatización de dichas alternativas y la dejación de funciones por parte. Se llega así a la percepción de que hay una disociación entre la cantidad de derechos proclamados y la inconsistencia en los modos, desviados del bien común, para conseguirlos. Y hay que incluir, además, la sospecha ciudadana de que los gerentes del bienestar social son importantes contribuyentes a la amenaza de ese bienestar (Beck, 2002).

Mientras que el relato de los derechos humanos podría seguir siendo válido, la verdad de su cumplimiento parece estar caducando en la forma prevista: el Estado como agente responsable de su garantía. El acelerado 
proceso de exclusividad en el disfrute de estos derechos, no es un fenómeno limitado a México; se trata de un patrón mundial, aunque el desbalance sea distinto en cada caso. Frente a esa situación, la reacción individual y colectiva es diversa en sus iniciativas. Es probable que La Santa Muerte sea vista como la esperanza eficaz, ${ }^{21}$ porque si el Estado no garantiza el acceso al disfrute de los derechos humanos ¿Dónde resuelvo mis problemas? ¿Cómo seguir vivo, no ser una estadística y ejercer una cierta función social? Quiero sugerir que en México se estaría dando un traspaso de las peticiones que normalmente se hacen al Estado hacia La Santa Muerte: trabajo, vivienda, una vida mejor, seguridad, educación, salud, como parte del repertorio que citan sus fieles, son asignables a las funciones del Estado, a través de sus aparatos. Se transfieren a La Santa Muerte las peticiones que, se supone, son exclusivas del Estado. Ella se va apropiando de las funciones de gobierno, retraducidas de colectivas a individuales, y se produce un traslape de una "cultura ciudadana" de logro colectivo a una de "resolver mi problema ahora mismo", en un escenario en el que los actores sociales se van modificando en personajes que, anónimamente, desdicen su ciudadanía y se promueven como creyentes de un símbolo-palanca con el que se impulsan hacia el mundo. La persona se impregna de la plusvalía que le otorga su trato con La Santa y eso le permite enfrentar lo que percibe como infranqueable, como en este ejemplo:

Por cierto, mi amiga fue quien primero me habló de La Santa Muerte. Ella misma tenía una imagen de La Santa Muerte. La Santa Muerte como un ente poderoso, pero celoso. Si comenzabas a adorarla, era para siempre. La Santa Muerte fue para ella también, un recurso para no gritar ante tanta sinrazón, culpa, rencor. Frente a La Santa Muerte todo adquiría sentido. ${ }^{22}$

En esta transferencia se configura la trasgresión de un modelo ético, el de los derechos humanos, y se siembran las semillas de otro horizonte. En dicho modelo ético se desambiguan muchos conglomerados agregados a la idea de orden obtenido a través de la autoridad, y la autoridad fundada en una jerarquía natural conformadora de mandato y obediencia unidireccional. En el imaginario de los derechos humanos no hay lugar para que la edad, el sexo, el color de la piel, la pertenencia a un grupo o creencia tengan fundamento como valores para oprimir. El deseo individual enfrenta el deseo de otras individualidades, obligando a la cooperación para lograr objetivos individuales que se hacen comunes. Sin embargo, ese proceso de construcción de ciudadanía en lugar de individualidades enfrentadas no se ha logrado en México, porque el Estado no ha realizado el esfuerzo formador en ese sentido (Castaingts Teillery, 1996: 64). El horizonte que se vislumbra en la ambigüedad que transporta el culto, donde vida y muerte valen igual, la imagen retorna a la jerarquía y la legitima como refundadora de relaciones desiguales: "primero Dios (o primero Satanás) y luego La Santa Muerte". Ya está construida la escalera de una relación asimétrica.

La Santa Muerte no abandera necesariamente la violencia exacerbada, pues quienes piden y legitiman muertes ajenas son pocos en relación con la gran masa de creyentes. Sin embargo, hay un elemento de violencia incluso en la relación individual más inocente con La Santa Muerte. En primer lugar porque la muerte perfila una amenaza a la vida, y ostentar a La Santa Muerte en el cuerpo impone temor o, al menos por instinto, una distancia o un interés distante y cargado de interrogantes. No ocurre la misma reacción con la imagen de la Guadalupana, por citar una figura amable. Por el contrario, La Santa Muerte ejercería una fuerte dosis de control social usando el miedo que pueda producir como revulsivo para quien la carga. Al mismo tiempo, frente a la percepción general de inseguridad, La Santa Muerte organizaría el espacio vital a favor de las demandas de sus creyentes.

El culto crece paralelamente a la recesión del estado mexicano como ancla y motor social de comportamientos. Al tiempo que los aparatos del Estado se diluyen, 
se mira hacia otros atractores, uno de los cuales, y no el menos importante, es esta Santa cuya imagen impregna valores que articulan socialmente los comportamientos que están actualizando México en este contexto de bifurcación. El otro referente importante para el comportamiento social es el de los derechos humanos, cuya precariedad coincide como indicador de la poca eficacia del Estado en sus funciones. Pero mientras los indicadores de uso y valor en los derechos humanos son los contenidos de las denuncias contra el Estado, el indicador de uso y valor en La Santa Muerte es el contenido de las súplicas en las oraciones individuales y en los rezos colectivos (trabajo, vivienda, que el negocio salga adelante, becas, salir de la cárcel, mejorar la conducta de algún familiar o la propia, amor, etcétera). En este caso, el aporte de la Santa sería de corrector de la incertidumbre provocada por el desdibujamiento del Estado como portador y garante de los derechos humanos. De alguna manera, al tiempo que el Estado deshace el tejido social y se despreocupa por valores como la redistribución de recursos y la cooperación, La Santa Muerte reteje los hilos rotos en una nueva textura de acumulación de individualidades y pérdida de ciudadanía, perfilando una identidad mexicana alrededor de la muerte como símbolo que ha construido como propio y que se le adjudica como característico. ${ }^{23}$

\section{Hacia otro análisis del culto a La Santa Muerte}

¿Es La Santa Muerte un fenómeno más de religiosidad popular? Si se aborda este movimiento social como una manifestación de la religiosidad popular hay que lidiar con la carga de definiciones e ideas que dicho concepto acarrea, y que asocia la religiosidad popular: la irracionalidad, la ignorancia, la superstición, la persistencia de cultos antiguos, la marginalidad, las pobres gentes, el parasitismo ritual. La religiosidad popular se analiza, además, dicotómicamente enfrentada con cualquier religiosidad institucional y siempre en detrimento de aquélla. De alguna manera, en ese enfoque el proceso de construcción cultural se queda corto al perderse en las comparaciones entre dos referentes desiguales. Hay, además, en el caso de las grandes religiones que han conformado culturalmente naciones-Estado un persistente interés en presentarse como formadoras de valores importantes para la humanidad. Puesto que la mirada, aquí, incide especialmente en el tipo de valores que se construyen en el culto a La Santa Muerte, la referencia de religiosidad popular puede devolver a la trampa expresada. Creo que la de la religiosidad popular no es una categoría suficiente para estudiar el fenómeno del amplio culto a La Santa Muerte, así como su atracción entre diferentes segmentos sociales y el efecto de su intervención social, pues no hay duda de que vestir complementos de La Santa Muerte, incorporarla a la propia piel mediante tatuajes, rezarle, confeccionar imágenes y altares, participar en rezos colectivos, regalarla a terceros, son acciones interventoras en las que los actores buscan hacerse fuertes en su estar en el mundo, y eso habla de control social.

En México, la representación en forma de esqueleto de la muerte ha formado parte, exitosamente, del proceso de construcción del país y su identidad (Lomnitz, 2006). Las calacas refieren vida y seres vivientes que expresan su conformidad o disensión con lo que sucede en el mundo. En un contexto así, La Santa Muerte no es vista como algo grotesco o de mal gusto. Comunica más bien un papel de marca social, un espacio de control social con significados impresos en la propia imagen: cuidado, no estoy solo o sola, tengo la protección de La Santa. La protección que se le supone a la imagen, aunque está construida desde éticas muy diversas, tiene el común denominador de referirse a la muerte y ésta contiene siempre la idea de fin, de límite, de frontera; dicho contenido es el que se resalta en todos los casos, sugiriendo un lema más o menos como éste: "la muerte está conmigo, y si está conmigo puede estar contra ti, por tanto es mejor que no me molestes". Es obvio que lucir La Santa Muerte provee de ventajas evidentes a quien lo hace porque le permite transitar con mayor confianza de éxito en una 
sociedad peligrosa, insegura y con fuerte incremento de muerte violenta y muerte social: los trabajos y posiciones que eran seguras antes ya no lo son por cambios de tendencias de mercado, valores y posiciones, por lo que muchas personas tienen que lidiar con problemas antes impensados, como trabajo, vivienda o pareja.

La figura y su culto emergerían como símbolo de defensa y referente amasador frente a las desventajas del globalismo ${ }^{24}$ socioeconómico y cultural (que no globalización amistosa), y que se caracteriza por un marco ético y de control social en el que el individuo se magnifica y se activa el desmantelamiento del Estado, la estructura organizadora del siglo XX por antonomasia. El Estado, en ese proceso, abandona sus elementos amables de protección social, se descarna y muestra lo más crudo de su estructura, dejando a la intemperie, y a disposición de cualquier depredador, a personas que han perdido la ocasión de hacerse ciudadanos y que retroceden a la condición de individuos que tienen que defenderse. Si el Estado se deslegitima al romperse como símbolo unificador de los eventos que han conformado la identidad mexicana y se hace productor de anomia social respecto a su ciudadanía, La Santa Muerte sería un referente re-organizador de ese estado de anomia, puesto que, aún siendo una figura de huesos, estos no están dispersos sino montados como figura humana completa que sólo carece de carne. Impregnada del límite igualador de la muerte, apropiaría la capacidad vigente del mexicano para sobrevivir a ese desmoronamiento eligiendo, de entre los muchos posibles, un símbolo poderoso, autoreferente y autoexplicativo: la muerte hecha santa, La Santa Muerte. La muerte como símbolo que a México le resulta cercano, amigable y dialogante, pareja y emparejadora. En ese entramado simbólico, elegir a La Santa Muerte como justiciera es señalar la ineficacia del sistema de impartición de justicia; del sistema de acceso a bienes y servicios de una forma indirecta. Es renunciar también a un ejercicio ciudadano de derechos y deberes $y$, por tanto, apartarse del imaginario de los derechos humanos. La Santa Muerte se expande como enlace entre zonas. No cuestiona ninguno de los poderes establecidos (incluida la fe católica) y se desmarca de adhesiones a dogmas. Refiere siempre una necesidad y lo necesario para su satisfacción a través de su intermedio. La fe en La Santa Muerte es una apuesta que involucra una actividad constructora de otra realidad social; se construye frente a instituciones inoperantes a pesar de las prohibiciones de la Iglesia Católica a la que pertenecen muchos de sus seguidores. Cada una de las peticiones a la Santa podría ser un indicador de lo que la ciudadanía valora y el Estado no garantiza. Si la muerte es anomia total, La Santa Muerte opera organizando la supervivencia. Se la invoca paraexistir a pesar de todo hasta el último día. Como mecanismo de control social informal actúa a modo de eficaz instrumento de supervivencia y autodefensa, porque quien la ostenta impone distancia y temor. Reorganiza la debacle, redistribuye las amenazas y orienta los objetivos. Los retos de la vida se imponen por influjo de su intervención. Inaugura otra ruta posible para la imposible existencia impuesta desde los despachos oficiales y desde la propia exasperante actuación humana. Implanta una ética social que reactiva valores y una manera de actuar particular. Ambas que se legitiman y hacen grupales por repetición y acaban formando un proyecto de sociedad que quizá no era parte del intento. Legitima, a su vez, un territorio social que fluctúa entre la desviación social y la inconsecuencia de las normas. En ese territorio alegal se impone como mecanismo de control social informal.

Quien se adscribe a La Santa Muerte ha traspasado la frontera del miedo al aspecto más intimidador de la muerte, y se la apropia cargada de significados; se la hace a su medida y moviliza esa plusvalía frente a quienes no le tienen fe. iLa Santa Muerte representa un modelo ético unívoco? Más bien estimula en sus seguidores sus referentes éticos preexistentes. Si quien la sigue pertenece a La Mara Salvatrucha 13, valores como la vida humana cobran tintes de ofrenda sangrienta. No ocurre así con el católico. Por tanto, en sí misma La Santa Muerte no transmite un patrón de univocidad de valores. Pero en el 
amplio espacio entre esos extremos radicales, donde se ubican muchosfieles, hay cierta univocidad de tendencias y procedimientos que educan o favorecen determinados hábitos, actitudes y valores ¿Cuáles son? Es fácil encontrarlos en las oraciones, con letras como éstas:

Oh gran Señora, vengo ante ti para pedirte que escuches a una devota tuya, que esta fe que deposito ante ti despierte el cariño, amor y pasión de (se dice el nombre) para que de día y de noche él estépensandoen mí y que toque las puertas de ésta tu casa. Que así sea.

Tráeme a 'Fulanito (a) de tal', quiero verlo humillado ante mí, quítale su voluntad para que no piense sino sólo en mí.

Muerte querida de mi corazón no me desampares con tu protección y no me dejes a Fulano de Tal un sólo momento tranquilo; moléstalo a cada momento, mortifícalo e inquiétalo para que siempre piense en mí.

Las oraciones filtran la imposición, el adueñarse de la voluntad ajena, el fin absoluto para los enemigos. La voluntad humana es aquí explosivamente individual: yo, mis intereses, mis deseos, que se ejercen frente y contra otros. Los curanderos consultados confirman que sus clientes tienen esta actitud. Mujeres que desean la muerte o la desgracia de quienes andan con sus maridos o buscan la sumisión total de la pareja; personas que quieren la ruina de negocios ajenos. El alcance del deseo de bienaventuranza se limita al círculo familiar y a los lazos de compadrazgo y amistad. La responsabilidad por las consecuencias de echar a andar esa voluntad se disuelve en la relación con La Santa, quien se encuentra más allá del bien y del mal legales. Es interesante señalar que las curanderas vinculadas con La Santa Muerte influyen en sus clientes al reencauzar sus deseos, con una notable contribución a la mejora ética. Un ejemplo es el relato que me hizo un curandero: ${ }^{25}$

Hay mujeres que llegan y me piden que haga para que vuelva su marido y se muera la mujer que está con él.
Yo les digo, 'itú que quieres de verdad?' Y ellas casi siempre contestan 'que vuelva mi marido'. Entonces yo les digo 'si quieres sólo a tu marido, deja que la otra mujer siga su vida, no le desees mal'. Casi siempre acaban aceptando y arrepintiéndose de haberse dejado llevar por la mala voluntad. Yo le pido a La Santa Muerte que les regrese el marido y ahí tengo muchos casos que les puede preguntar... Si siguen queriendo la muerte de la otra, ahí yo no quiero saber nada. Pero casi siempre les ayudo a pensar y a querer su bien y no el mal para otros.

Otro curandero ${ }^{26}$ insiste en su interés por desviar a sus clientes de las ideas de venganza, males ajenos y desgracias para quienes se cruzan en su camino. Según él las personas acaban por desear sólo el bien para sí mismas y olvidan desear el mal ajeno tras hablar sobre los términos de las peticiones a La Santa Muerte.

\section{Comentario final}

Es posible que el florecimiento del culto a La Santa Muerte sea coyuntural, pero mientras tanto se está operando con programas éticos ambivalentes y bajo la responsabilidad individual de quien intercede ante la imagen. El colectivo humano deja de ser nucleante para la decisión porque los deseos se dirigen contra otros. Las oraciones se construyen con la elección de términos preposicionales contra y bajo, soslayando preposiciones solidarias e igualitarias. Si se piensa en el culto a La Santa Muerte como un imaginario motriz ${ }^{27}$ de comportamientos se puede advertir que redunda en la legitimación de nuestra aptitud para la violencia, en el control social a través del temor, en la confirmación de la jerarquía como fuente de las relaciones desiguales y con el único freno a la ambición individual: el que imponeel favor o disfavor de La Santa. Y si comparamos este metarrelato con el de los derechos humanos, no es imperceptible la diferencia de los fundamentos en que ambos se asientan. La Santa iguala con la muerte y ese rasero 
infunde temor, sumisión y control, aunque también ímpetu para sobrevivir. Los derechos humanos resaltan la igualdad desde el nacimiento de los seres humanos y hacen a cada uno copartícipe del bienestar individual y común. La apuesta por uno u otro imaginario no está perdida o ganada. Pero el proceso parece decantarse hacia la muerte sustituta, esa Santa Muerte que inhibe la construcción de una cultura de los derechos humanos, una cultura de ciudadanos y ciudadanas.

\section{Notas}

${ }^{1}$ Elsa Malvido y Katia Perdigón son nombres de referencia constante en esos artículos.

${ }^{2}$ Se trata de un local que funge como iglesia de la confesión "Iglesia Católica Tradicional, México-Estados Unidos"

${ }^{3}$ Carlos Navarrete.

${ }^{4}$ La Santa Muerte ocupa valores diferentes según vista de color amarillo, rojo, verde, negro, blanco, etcétera, y según las ofrendas y promesas que se le hagan para cada petición y como rutina.

${ }^{5}$ Entrevista con sacerdote católico en San Cristóbal de Las Casas, Chiapas. Julio de 2007.

${ }^{6}$ (Entrevista con miembro, 2006). Los Maras son bandas muy estructuradas, de interés nacional e internacional en el marco de los grandes movimientos de población entre Centroamérica, México y Estados Unidos, en las últimas décadas del siglo XX y en el XXI. La Mara Salvatrucha 13 rinde culto obligadamente a La Santa Muerte como intermediaria con Satanás.

${ }^{7}$ En la Iglesia dedicada a San Pascualito Rey, en Tuxtla Gutiérrez, durante una visita en 2006, observé una imagen de La Santa Muerte en la capilla lateral izquierda más cercana al altar central.

${ }^{8}$ Hay muchas modalidades de calavera y cada una refiere significados distintos. Por ejemplo, la calavera pirata es un cráneo con dos huesos cruzados en su base. La calavera del lugar arqueológico de Toniná es un esqueleto de cuerpo entero con restos orgánicos en su rostro, en acción, con una mueca sonriente, etcétera.
${ }^{9}$ Información que debo a Francisco Chong Villarreal, quien por su trabajo ha mantenido conversaciones formales e informales con personas con estas características, seguidoras de La Santa Muerte en el Soconusco.

${ }^{10}$ En la revista Devoción a La Santa Muerte (Naucalpan, Estado de México, editada por Mina, S.A.) hay una sección titulada Doy Gracias, en la que se agradece a La Santa Muerte por los motivos indicados. En la sección Testimonios ocurren ejemplos similares. Estos motivos coinciden también, con los señalados en las entrevistas realizadas en 2005, 2006 y 2007, en Chiapas y México, D.F.

${ }^{11}$ Los Maras son bandas muy estructuradas, de interés nacional e internacional en el marco de los grandes movimientos de población entre Centroamérica, México y Estados Unidos, en las últimas décadas del siglo XX y en el XXI. La Mara Salvatrucha 13 rinde culto obligadamente a La Santa Muerte como intermediaria con Satanás (Entrevista a miembro, 2006).

${ }^{12}$ Devoción a La Santa Muerte número 35; primera quincena de noviembre de 2006, página 23, Testimonio: "Con su ayuda, mi hermano cambió (de tomador, sin trabajo y violento a abstemio, trabajando y con novia)".

${ }^{13}$ Conversación de la autora con miembros de una Mara en 2006.

${ }^{14}$ Este culto tiende a la exclusividad no por expresa prohibición, sino para dar gusto a La Santa, a quien no le gusta compartir espacio. Es celosa y un entrevistado señaló que es la santa más marginada, por eso va sola.

${ }^{15}$ Entre los principales promotores en el Distrito Federal, los medios señalan a Manuel Valadez, en el Mercado del Sonora. Doña Enriqueta (o doña Queta) en Tepito, así como a David Romo, religioso de la Iglesia Católica Tradicional, México-Estados Unidos. En el país es famoso el culto a San Pascualito Rey (Tuxtla Gutiérrez, Chiapas), al que reconocen como Santa Muerte. En el mismo estado hay curanderos con culto abierto o privado en ciudades como San Cristóbal de Las Casas y la presencia de La Santa Muerte en mercados y comercios es común en varios lugares (Tapachula, Comitán, Ocosingo, etcétera). 
${ }^{16}$ Conversación con una devota de La Santa Muerte, compartida por Francisco Chong Villarreal, 2007, Chiapas.

${ }^{17}$ La guadaña segadora es la medida de alcance de un movimiento de brazo; el mundo simboliza el reinado humano (el límite que se le supone: todo eso, pero no más de eso).

${ }^{18}$ Segundo Considerando del Preámbulo de la Declaración Universal de los Derechos Humanos de 1948.

${ }^{19}$ He elegido este texto de la Declaración de México porque destaca la brecha entre unos derechos humanos reconocidos y una realidad que los desmiente. Incluye otros países además de México; los mismos que son expulsores de personas que cruzan México indocumentadas y entre las que hay muchas seguidores de La Santa Muerte "para tener éxito".

${ }^{20}$ Nota de la agencia EFE, 7 de diciembre de 2006, México.

${ }^{21}$ La Santa Muerte ostentada reduce el anonimato porque fija la atención ajena y plantea escenarios de control que, sin ella, no se hubieran dado. De alguna manera construye identidad.

${ }^{22}$ Aportación de Francisco Chong Villarreal, fruto de su relación con seguidores de La Santa Muerte (junio de 2007).

${ }^{23}$ Entre septiembre y diciembre de 2007, en el Centro de Historia de Zaragoza (España) se pudieron ver fotografías de La Santa Muerte tomadas en México y muchos comentarios asociaban a este país con la muerte, como se asocia el baile flamenco con Andalucía o la Coca-Cola con Estados Unidos.

${ }^{24}$ Tomo el término de globalismo del sociólogo alemán Ulrich Beck, quien lo distingue de globalización (que es el más extendido en los medios). Beck inscribe al globalismo en la reducción de todos los modelos económicos a un solo modelo impuesto en el que desaparece el ente ciudadano, sustituido por el ente inversor. Para efectos de este artículo me parece mucho más adecuado este término que el de globalización, que resulta ambivalente y poco preciso.

${ }^{25}$ Este tipo de situación fue repetido en más o menos los mismos términos por otros dos curanderos de 21 y 50 respectivamente.

${ }^{26}$ Entrevistas realizadas en 2006 y 2007 en San Cristóbal de las Casas, Chiapas.
${ }^{27}$ En el sentido en que los seguidores le otorgan una vocación totalizadora, que pretende dar respuesta y solución a cualquier circunstancia.

\section{Bibliografía}

Alfaro, Alfonso, 2003, "La Santa Muerte y el cuerno de chivo" en Artes de México, núm. 67, octubre, México.

Álvarez Santaló, Carlos et.al., 2003, La religiosidad popular I. Antropología e historia. Barcelona, Anthropos.

Ambrosio, Juan, 2003, La Santa Muerte. Biografía y culto, Planeta, México.

Aridjis, Homero, 2003, La Santa Muerte, Alfaguara, Conaculta, México.

Barranco, Bernardo, 2005, "La Santa Muerte", en La Jornada. 01 de junio, www.jornada.unam.mx.

Beck, Ulrich, 2002, La sociedad del riesgo global, Siglo XXl, Madrid, España.

Castaingts Teillery, Juan, 1996, "México: crisis simbólica y crisis económica”, Espiral. Estudios sobre Estado y Sociedad, vol.II, núm. 6, mayo-agosto, pp. 59-78.

Castellanos, Laura, 2004, "La Santa de los desesperados", en Masiosare 333, 9 mayo.

Castells Ballarin, Pilar, 2002, El descanso de los muertos. Un concepto en evolución, Tesis doctoral, Universidad de Barcelona, Barcelona.

Devoción a La Santa Muerte, revista publicitaria de La Santa Muerte, registrada en Naucalpan, Estado de México, quincenal, editada por Corporativo Mina, S.A.

García Ayluardo, Clara y Manuel Ramos Medina (editores), 1997, Manifestaciones religiosas en el mundo colonial americano, INAH, Centro de Estudios de Historia de México (Condumex) y Universidad Iberoamericana, México, segunda edición corregida

Pardo, Gastón, 2005, "El culto mexicano de La Santa Muerte gana espacio en la Mara Salvatrucha”, en www.redvoltaire.mx, 12 de agosto.

Geertz, Clifford, 1989, "El impacto del concepto de cultura en el concepto del hombre", en La interpretación de las culturas, Gedisa, Barcelona, pp. 43-59. 
Gruzinski, Serge, 1990, La guerra de las imágenes. De Cristóbal Colón a Blade Runner (1492-2019), FCE, México.

Lomnitz, Claudio, 2006, Idea de la muerte en México, FCE, México

Malvido, Elsa, 2004, página de Noticias del Conaculta, agosto.

—, 2005, "La Santa Muerte", en Arqueología, núm. 76.

National Geographic, 2005, diciembre.

Navarrete, Carlos, 1982, "San Pascualito Rey y el culto a la muerte en Chiapas", en Etnohistoria; Serie antropológica, núm. 46, UNAM, primera edición, México.

ONU, www.onu.org.

Pacheco Colín, Ricardo, 2004, "El culto de La Santa Muerte llega a Los Ángeles y Sudamérica”, en La Crónica, 15 agosto.

Pacheco, Laura Emilia y Fernando Castillo (fotógrafo), 2005, "Código postal: La Santa Muerte", en National Geographic en español, vol.17, núm. 6, diciembre.
PNUD, 2002, Informe sobre Desarrollo Humano. Resumen ejecutivo, México.

—, 2004, Informe sobre Desarrollo Humano. Resumen ejecutivo, México.

—, 2006, Informe sobre Desarrollo Humano. Resumen ejecutivo, México.

Talavera Solórzano, Leticia y Mariano Monterrosa Prado, 2002, Las devociones cristianas en México, INAH, Plaza y Valdés, México.

UNESCO, 2001, Declaración de México sobre educación en derechos humanos en América Latina y el Caribe, Ciudad de México, 28 de noviembre-01 de diciembre.

Colaboradores de Wikipedia, 2007, Santa muerte (en línea), Wikipedia, la enciclopedia libre, Santa Muerte (en línea), http://es.wikipedia.org/w/index.php?title=Santa_ Muertedeoldid=7112496. 